\title{
The Transformational Learning of Three Adult Academicians
}

\author{
Üç Yetişkin Akademisyenin Transformatif Ö̆̆renmesi
}

\section{Mehmet ŞAHIN* \\ Yavuz ERIŞEN** Nadir ÇELIKKÖZ ${ }^{* * *}$}

\begin{abstract}
Mezirow (1991) defines transformative learning as a theory about constructing meaning, not just about knowledge acquisition, and the construction of meaning is about learning through critical reflection, rather than mindlessly or unquestioningly acquiring frames of reference through life experiences. Mezirow (1997) emphasizes that transformative learning is rooted in the way human beings communicate, and does not link it exclusively with the significant life events of the learner. Thus, the individual can make shifts in his/her world view and this can result in a more inclusive world-view. This qualitative article based upon transformative learning theory presents the common changes and transformations of three adults, following their movement to a new city and university as academicians.
\end{abstract}

Keywords: Transformation, Transformative Learning, Adult Learning, Academician, Change

Öz: Mezirow'a göre (1991), yalnızca anlam oluşturan bilgiyi edinme ile ilgili olmayan ama anlam oluşturma ile ilgili kuram olan transformatif öğrenme kuramı, zihni kullanmadan veya sorgulamadan yaşam deneyimleri ile referans çerçeveleri edinmek yerine bu işi eleştirel düşünme ile yapmayı öğrenmektir. Mezirow (1997) transformatif öğrenmenin insanların iletişim biçimlerinde temellendiğini, yalnızca öğrenenin önemli yaşam olayları ile bağlantılı olmadığını vurgulamaktadır. Böylece bireyin kendi dünya görüşünde değişimler meydana gelmekte ve bu değişiklik daha genel bir dünya görüşü üretebilmektedir. Nitel bir araştırma olan bu makale transformatif öğrenme kuramına dayalı olarak üç yetişkinin akademisyenin yeni bir şehre ve yeni bir üniversiteye geçiş yapmalarından sonra yaşadıkları değişimler ve dönüşümleri ortaya koymaktadır.

Anahtar sözcükler: Transformasyon, Transformatif Öğrenme, Yetişkin Öğrenmesi, Akademisyen, Değiş̧im

\section{Introduction}

"I am in no degree ashamed of having changed my opinions. What physicist who was active in 1900 would dream of boasting that his opinions had not changed?"

\section{Bertrand Russell}

There have been theories, models and perspectives on learning under behaviorism, cognitivism, constructivism and connectivism. They all make use of various approaches to focus on the nature and process of learning. In addition the transfer of learning is another focus where the

\footnotetext{
*Assoc. Prof. Dr., Y1ldız Technical University, Faculty of Education, İstanbul. sahinmehmet033@gmail.com

** Assoc. Prof. Dr., Yıldız Technical University, Faculty of Education, İstanbul. yverisen@yildiz.edu.tr

*** Assoc. Prof. Dr., Yıldız Technical Universit, Faculty of Education, İstanbul. ncelikoz@gmail.com
} 
dependency of human conduct, learning, or performance is upon prior experience. The notion is not a new one and goes back to the idea of transfer of practice by Edward Thorndike and Robert S. Woodworth. The focus here is on how individuals transfer learning from one context to another similar context, or how "improvement in one mental function" can influence a related one. However, the main focus is on the prior knowledge, which is usually described as the process and the effective extent to which past experiences affect learning and performance in a new situation.

However, there has been another approach to learning that helps individuals to transform with the help of their new learning. Here, the shift is from prior learning to new learning. The focus is on the idea of people changing the way they interpret their experiences and their interactions with the world. This approach is termed "Transformative Learning Theory". Transformative learning has a history of several decades. The study of transformational learning emerged with the work of Jack Mezirow (1981; 1994; 1997). However, according to Kitchenham (2008), Mezirow was influenced by Habermas' three types of knowledge or domains of learning: instrumental or technical, communicative or practical, and emancipatory. Instrumental learning focuses on objective empirical knowledge derived from the scientific method and is concerned with "learning to control or manipulate the environment or other people, as in task-oriented problem solving". Mezirow (1991) defines learning as the process of using a prior interpretation to construe a new or a revised interpretation of the meaning of one's experience in order to guide future action.

However, the term transformation is often confused with the term change. Transformation is understood to be a radical change, and thus is a subset of change. To understand transformative learning, one must discriminate between what is change and what is transformation. To transform means to go beyond or across structure; to change completely, essentially composition, or structure; or a metamorphosis (Scott 2006).

Mezirow developed his characterization of transformative learning in the late 1970's and early 1980's. Mezirow published research concerning the processes and changes that 83 adult women went through when they returned to college in 1975. Based on this research, he concluded that these women had undergone a change in perspective as a result of their experiences. In parallel with his research results, he continued to refine his thinking and his model of perspective transformation. Finally, he (1978) characterized his theory as "a structural change in the way we see ourselves and our relationships".

Mezirow (1991) defines transformative learning as a theory about making meaning, not just about acquiring knowledge, and "[m]eaning is making sense of or giving coherence to our experiences". Making meaning is about learning through critical reflection, rather than mindlessly or unquestioningly acquiring frames of reference through life experiences. Thus, transformative learning, according to Mezirow (1991), can be viewed as "an enhanced level of awareness of the context of one's beliefs and feelings, a critique of one's assumptions, and particularly premises, and an assessment of alternative perspectives”. In 1991, Mezirow introduced three types of reflection (content, process, and premise) and their roles in transforming meaning schemes and perspectives; he notes that critical reflection on one's premises can result in a much more profound transformation than through content or process reflection (Mezirow 1991). Mezirow (1997) emphasizes that transformative learning is rooted in the way human beings communicate, and does not link it exclusively with significant life events of the learner. Through this combination of reflection and discourse, the individual can make shifts in his/her world view and this can produce a more inclusive world-view. This is one of the 
benefits of transformational learning as it leads to the development of greater autonomy as a person, a defining condition of adulthood (Mezirow 1997). Mezirow (1997) identified several ways to stimulate transformational learning, including journal writing, metaphors, life history exploration, learning contracts, group projects, role play, case studies, and using literature to stimulate critical consciousness. He believed that these could stimulate critical reflection and rational discourse, integral parts of the transformative process in his model. Later, in 1998, Mezirow refined the three types of reflection into two dimensions of critical reflection - the objective and subjective critical reflection on and of assumptions (Kitchenham 2008). More recently, Mezirow (2003) stated that "transformative learning is learning that transforms problematic frames of reference - sets of fixed assumptions and expectations (habits of mind, meaning perspectives, mindsets) - to make them more inclusive, discriminating, open, reflective, and emotionally able to change".

Clark (1993) defined transformational learning as learning that induces more far-reaching change in the learner than other kinds of learning, especially learning experiences which shape the learner and produce a significant impact, or paradigm shift, which affects the learner's subsequent experiences.

King (2002) stressed the idea of a fundamental change in perspective or frame of reference, which is at the heart of transformative learning. According to King, when someone undergoes such a change, he has, in essence, "transformed" his view of himself or of the world or of how he interacts with others and his environment.

Dr. Patricia Cranto, another leading writer on transformative learning, stated that the "elegantly simple" definition of TL includes the idea of people changing the way they interpret their experiences and their interactions with the world: “... an individual becomes aware of holding a limiting or distorted view. If the individual critically examines this view, opens herself to alternatives, and consequently changes the way she sees things, she has transformed some part of how she makes meaning out of the world".

Mezirow (1991) described this transformation of perspective as going through ten ordered phases. In order for people to develop their frames of references to be more inclusive, discriminating, open, reflective, and emotionally able to change, transformations, within awareness, often involve a progression through ten stages:

- A disorienting dilemma

- A self examination with feelings of guilt or shame

- A critical assessment of epistemic, socio-cultural, or psychic assumptions

- Recognition that one's discontent and the process of transformation are shared and that others have negotiated a similar change

- Exploration of options for new roles, relationships, and actions

- Planning a course of action

- Acquisition of knowledge and skills for implementing one's plan

- Provisional trying of new roles

- Building of competence and self-confidence in new roles and relationships

- A reintegration into one's life on the basis of conditions dictated by one's perspective

As mentioned above, there have been supporters of transformative learning theory and the supporting research has greatly enriched the theory and, consequently, the theory has undergone numerous modifications over the past decades. However, there have also been challenging 
ideas like that of Taylor (2006) who stated that Mezirow places the individual at the center of the transformative process, which is very autonomous and individualistic. Generally, the criticism of transformational learning is its lack of importance for social change, social context, and cultural context. Another criticism is the emphasis that Mezirow places on rationality. According to Taylor (2006), transformational learning is a process dependent upon the need for support, trust, friendship, and intimacy; but he acknowledges that not much is known about these more subjective roles and further research needs to take place. In addition, Clark and Wilson (1991) state that Mezirow disregards contextual elements (socio-cultural and historical) in order to generalize a process of perspective transformation and promote individual agency.

In summary, transformative learning theory is a framework that provides a structure and process that sheds light mainly on the rational aspect of adult learning within awareness. It asserts that the frames of reference influence and shape individuals, whether or not they are aware of them. It provides a structure that illuminates how individuals can become conscious of their prior assumptions, critically reflect upon these assumptions, and develop strategies and actions to transform them and thus they can create their own frames of references and create their own unique world view.

\section{The Significance and Aim of the Study}

Mezirow (1997) considered critical reflection to be the distinguishing characteristic of adult learning, and saw it as the vehicle by which one questions the validity of one's world-view. He identified rational discourse as a catalyst for transformation, as it induced the various participants to explore the depth and meaning of their various world-views, and articulate those ideas to their instructor and classmates. Thus, what is expected from transformational learning is that the individuals come to understand that they've held a limiting view of the world or of how things work, and they adjust their thinking to accommodate a more accurate or expansive understanding. The transformation can be in the form of disciplinary realizations or of self understanding in relation to the world. He identified several ways to stimulate transformational learning, including journal writing, metaphors, life history exploration, learning contracts, group projects, role play, case studies, and using literature to stimulate critical consciousness.

The article is based on the type of transformation which describes the conditions and processes necessary to transform assumptions, concepts, values, and practices that constitute a way of viewing reality. The main focus is on the paradigm shifts or perspective transformations rather than the development psychologists' employment of different developmental theories to describe the process of adults' personal growth and development. In this context, Mezirow proposed (1991) that "it is not so much what happens to people but how they interpret and explain what happens to them that determines their actions, their hopes, their contentment and emotional well-being, and their performance".

In short, transformational learning theory is about making sense of our experiences; it is a meaning-making activity. However, meaning making in transformative learning is different from everyday learning for the reason that "normally, when we learn something, we attribute an old meaning to a new experience. However, in transformative learning, we reinterpret an old experience (or a new one) from a new set of expectations" (Mezirow 1991). Therefore, this article aims to present the transformational learning process of three academicians (researchers) based on their personal experiences as adults, focusing on the paradigm shifts or perspective transformations. The first major component of transformative learning is meaning perspective. According to Cranton \& Roy (2003), a meaning perspective is a frame of reference, which 
includes assumptions and expectations that build through life experiences, and "has two dimensions - a habit of mind and the resulting points of view". Transformational learning is unsettling in that it leads to questioning of accepted assumptions and views and to new ways of knowing and understanding.

This article is mainly related to the first stage of the phases mentioned by Mezirow. The first stage, a disorienting dilemma, can take many forms. It could be a life crisis, a distressing transition, or an experience that deviates from our expectations or assumptions about the state of things. This phase also leads to questioning of accepted assumptions and views and to new ways of knowing and understanding. In this article, the assumptions, expectations, views and principles of three academicians are adddressed and the transformed forms or new ways are presented based on their experiences in the three years following their "emigration" to a metropolitan city, Istanbul, and to a metropolitan university, Yıldız Technical University, from a typical Anatolian university, Selcuk University in Konya.

\section{Method}

This is a qualitative study that aims to present the key features of the transformational learning theory and focuses upon the transformational process of three academicians (researchers) based on their personal experiences as adults, focusing on their common paradigm shifts or perspective transformations. What makes the study phenomenological is that the focus is upon the intellectual, psychological, and moral dimensions of learning that foster personal and social change (Wyandotte \& Huh 2012). To this end, the data is based on the works on the transformational learning theory and the researchers' own experiences of disorienting dilemmas. This article aims to present the common transformational learning process of three academicians (researchers) based upon their personal experiences as adults, focusing on the paradigm shifts or perspective transformations commonly seen as an integral part of transformative learning. The assumptions, expectations, views and principles of the three academicians are addressed and the transformed forms or new ways of understanding and thinking are presented, based upon their experiences in the three years following their "emigration" to a metropolitan city, Istanbul. Istanbul is metropolitan city with a national and international population of around 25 million. The general belief concerning Istanbul is that Istanbul itself is a university and when a student graduates from a university, that student, in fact, has two diplomas: one from the official university and one from the "Istanbul" university, the informal learning centre. The common experiences of the participant researchers also covers their common academic dilemmas as they "emigrated" to a metropolitan university, the Y1ld1z Technical University in Istanbul, from a typical Anatolian university, Selcuk University in Konya. The common shifts, changes and experiences of the researchers at both city and university level are analyzed here from the transformational learning theory principles.

The learning curve of the participants of the present study includes a disorienting dilemma that eventually leads to a perspective transformation. Once the learner has come to a new understanding, stages five to seven involve exploring and planning a course of action that will reaffirm the transformative process in steps eight to ten (one either accepts the course of action, or rejects the course of action and designs a new plan). Mezirow states that the transformation experience may be encountered in various ways and that is not necessary for a person to experience all of the phases, or even in a set order (Kitchenham 2008).

\section{Participants and Setting}

The participants of this study are the three academicians and co-authors of this paper. The age 
range is between 45 and 50. The participants had the following common state of mind and feelings before moving:

- There was an increase in anxiety level just before and after the arrival to Istanbul, despite before Konya the experiences of many years in the capital city, Ankara, and despite twenty years of academic experience.

- Konya, with a population of around one million, was the city where they worked, for as many as ten years as academicians after Ankara. The city life was regular, economical and with easy transportation.

- From the children's view, Konya was equipped with the opportunities and facilities of education and educational institutions, maintaining local values as the basis of socio-cultural structure, and social and humane relations with the neighbors etc. This led to the satisfaction of family members.

- Despite short trips to Istanbul before moving, the changed aim of settlement and work, caused fear. The possible factors of fear were the large population number, the high cost of living, the slow working of the health procedures and the lower level of education for the children which provided the main reasons for the dilemmas.

\section{Data Collection}

In this qualitative study, two data gathering techniques were adopted: the features and processes of transformative learning theory were explored with the help of the works written on the theory. The second technique was used to collect the data on the transformational learning experiences of the three academicians as participating researchers. They talked, discussed and took notes of the learning stages they experienced from the time they "emigrated" to Istanbul and began teaching at the university in Istanbul. The time period extended from June 2013 to September 2015. The starting characteristics of the participants have common points: three of them came from the same university and the same city at the same time to the same university in the same city. The notes taken by the researchers were coded and analyzed considering the aim of the study. Then, the data were categorized according to the common themes. Five external experts were involved in the formation of the themes and categories for validity and reliability.

\section{Findings}

"Transformational learning shapes people" Clark asserted $(1993,47)$ "they are different afterwards, in ways both they and others can recognize". Transformational learning is related to the place where an individual is changing and who he or she is, in interaction with the environment and the knowing domains to be immersed in. It is directly related with reflection to find the meaning of a learning experience, and adduction to bring that meaning into future action. Mezirow's theory stresses four transformation domains. According to transformational learning theory, learning occurs in one of four ways: by elaborating existing frames of reference, by learning new frames of reference, by transforming points of view, or by transforming habits of mind.

Financial dilemmas: Anxiety about possible financial problems in Istanbul: expensive accommodation, high cost of living, high cost of schooling for children, high cost of transportation, high cost of subsistence, insufficient and high cost of health facilities. These challenges led to following ways of thinking:

- A glass of tea is no longer a glass of tea. It means something different if it is 
drunk by the seaside or in a high class space.

- Parking is no longer placing the car in an empty space but fulfilling some other processes and bureaucracy like queuing rules, billing and paying cards.

- Money is not just money, it means searching for the proper prices, selecting the best for the money, eating and drinking directly money instead of meals or food.

- New criteria for spending money and payment as the money you have has been devalued.

Dilemmas arising from educational facilities for children: the lower level of educational facilities despite the higher cost, lower quality and standards in both private and state schools. These differences triggered the following changes in thought:

- Education is a sector and a concern of trade. The exam results or proficiency levels also indicate the level of schooling fee but does not necessarily indicate the level of education.

- Slow and demanding process of adaptation to the school, the students and the working of the school administration.

- More time and distance spent in getting to school but not higher schooling facilities and materials.

- Variety of students with various physical and social environments and multi way culturing function of schools.

- Need for better thinking, planning and decision making skills.

Challenges in the work conditions: different university work and cultural conditions and working habits, prejudices about academic understanding, about academic proficiency and characteristics, adaptation and adoption processes:

- Hard approval and acceptance process to teach at university

- Not to be adopted and assimilated by other colleagues with their prejudices regarding social, cultural values and the political concerns of discrimination

- Inferiority complex of existing fellows created with the higher academic title

- More academic efforts and work for more productivity

- More empathy for a balanced work atmosphere

- More formal relations than informal relations

Change in the accommodation conditions: new settlement and environment both physically and socially, insufficient social and leisure activities and facilities, long distance between the settlement and the new campus, new and very different neighbors (if any). The new conditions led to the new ways of understanding as follows:

- Accommodation and dealing with estate agents for the first time

- Learning the details of buying or renting a flat or house

- Differentiate and determining the necessity levels of the rooms or spaces in a flat

- Living with others that have different cultures and habits of living

- The details of investing in property

New commuting and timing: different ways of transportation for commuting, much heavy traffic, very long time spend on the way, starting to use navigation tools for traffic and time management. The following are the resultant ways of thinking.

- Using new and compulsory technical tools: Due to different forms of 
transportation, new technical tools for navigation, weather conditions, mobiles and search engines.

- Management of time is of high importance as it relates both to the heavy traffic and the slow rate of transportation.

- Not hours but minutes are very critical in terms of timing

\section{Discussion and Suggestions}

The term 'Transformational Learning' has been used in varied ways and with varied meanings. At its simplest, Transformational Learning is learning that takes the learners' knowledge and skills into a different or new domain, with a jump in step in cognitive and affective processes. In the transformational learning theory, the emphasis is on individual or social change. This change can be in the intellectual, psychological, and moral dimensions of learning and it can foster personal and social change. In this way, individuals can develop their consciousness of their own and of others' thoughts, language, and reasoning, allowing them to direct their thinking more strategically to specific intentions (Wyandotte \& Huh 2012).

Transformative learning gives adult learners the ability to think autonomously because it allows learners to develop their own sense of meaning in a world free from the accepted purposes, beliefs, judgments, values, and feelings that we received from our cultures, religions, family beliefs, personalities, and life experiences. In this way, individuals will fully participate in a democratic society and will be able to make their moral decisions.

As for adult learners, they will inevitably join the workforce and truly take ownership of social and personal roles in helping our society and world to become better. Considering the mentioned characteristics of transformative learning theory, there have been changes and transformations in the following domains:

- Transformation in the decision making process

- New approach and more emphasis on planning

- More punctual and precise timing and action

- Larger space in understanding and empathy

- Fewer conflicts of values and feelings

- Acting more professionally rather than impulsively

- Improvement in management

- New assessment and evaluation criteria for financial acts

- More emphasis on leisure time and activities for familial and one's own benefit

Transformational learning theory can't be regarded as an independent learning approach. In essence, it can be related to Piaget's Constructivism which lays stress on Assimilation, Accommodation and Equilibration as stages in the formation of new learning. According to Piaget (1985), while cognitive development proceeds, new schemata are developed and existing schemata are more efficiently organized to better adapt to the environment. In the assimilation stage, there are attempts to organize existing schemata for a better understanding of events in the external world. In the accommodation stage, the pre-existing schemata changes so as to adapt to a new situation.

In addition, transformational learning theory is not far distant from Problem-based learning. It is a student-centered pedagogy in which the students learn about a subject through the experience of solving an open-ended problem. Students learn both thinking strategies and domain knowledge. Problem based learning addresses the need to promote lifelong learning 
through the process of inquiry and constructivist learning (Schmidt et al. 2011). In this way, it can also be a part of adult learning, in terms of its approach to learning.

However, although the transformative learning theory can be suggested as a learning theory mainly for the adults, it needs to be revised and modeled in terms of the roles involved in a learning activity. Thus, when transformative learning is the goal of adult education, fostering a learning environment in which it can occur should consider the role of educator, the role of the learner, the role of professional development for the educator and the role of the rational and the affective domains.

\section{REFERENCES}

Clark M. \& Wilson A. (1991). “Context and Rationality in Mezirow’s Theory of Transformational Learning”. Adult Education Quarterly 41/2 (1991) 75-91.

Cranton P. \& Roy M. (2003). "When the Bottom Falls Out of the Bucket: Toward a Holistic Perspective on Transformative Learning”. Journal of Transformative Education 1/2 (2003) 86-98.

King K. P. (2002). A Journey of Transformation: A Model of Educators' Learning Experiences in Educational Technology. Eds. J. M. Pettit \& R. P. Francis. Raleigh 2002.

Kitchenham A. (2008). “The Evolution of John Mezirow's Transformative Learning Theory”. Journal of Transformative Education 6/2 (2008) 104-123.

Mezirow J. (1978). “Perspective Transformation”. Adult Education Quarterly 28/2 (1978) 100-110.

Mezirow J. (1991). Transformative Dimensions of Adult Learning. San Francisco 1991.

Mezirow J. (1997). "Transformative Learning: Theory to Practice”. Eds. S. Imel, J. M. Ross-Gordon \& J. E. Coryell. New Directions for Adult and Continuing Education (1997) 5-12.

Mezirow J. (2003). "Transformative Learning as Discourse". Journal of Transformative Education 1/1 (2003) 58-63.

Piaget J. (1985). Equilibration of Cognitive Structures. Chicago 1985.

Schmidt H. G, Rotgans J. I, Yew E. HJ (2011). "The Process of Problem-Based Learning: What Works and Why”. Medical Education 45/8 (2001) 7.

Scott S. (2006). "A Way of Seeing: Transformation for a New Century”. Eds. T. Fenwick, T. Nesbit \& B. Spencer. Contexts of Adult Education: Canadian Perspectives (2006) 153-161. Toronto.

Taylor E. W. (2006). "A Critical Review of the Empirical Research of Transformative Learning (19992005)". The Adult Education Research Conference, Minneapolis, MN.

Thorndike E. L. \& Woodworth R. S. (1901) "The Influence of Improvement in One Mental Function Upon the Efficiency of Other Functions”. Psychological Review 8/4 (1901) 384-395.

Wyandotte A. \& Huh S. (2012). Of Toads, Gardens, and Possibilities: A Phenomenological Approach to Transformative Education. 